\title{
PRAWNY ASPEKT MISYJNEJ DZIAŁALNOŚCI LUDU BOŻEGO
}

Zakończony w grudniu 1985 r. Nadzwyczajny Synod Biskupów dał nowy impuls do studiowania nauki Soboru Watykańskiego II. Relacja końcowa Synodu głosi, że orędzie Soboru Watykańskiego zostało przyjęte przez cały Kościół oraz jest i pozostanie dla przyszłych czasów „Wielką Kartą" ". „Ta Wielka Karta” Kościoła wprowadzająca go w trzecie tysiąclecie istnienia winna być gruntownie poznana i realizowana. Nawiązując do powyższego postulatu Synodu, niniejszy artykuł zamierza ukazać Soborową wizję Kościoła misyjnego i wypływające z niej przepisy prawne, wyrażające odpowiedzialność całej wspólnoty Ludu Bożego za jego działalność misyjną. Nie zamierzamy przedstawić całokształtu działalności misyjnej Kościoła i związanych z nią przepisów prawnych ${ }^{2}$, lecz jedynie rolę i aktywność misyjną poszczególnych członków Ludu Bożego $\mathrm{w}$ aspekcie prawnym.

\section{MISYJNY CHARAKTER WSPOLNOTY LUDU BOŻEGO}

Sobór Watykański II przypomniał i pogłębił ewangeliczną prawdę o powszechnym nakazie Chrystusowym głoszenia zbawiennej prawdy na całym świecie i po wszystkie czasy. Obowiązek ten spoczywa na każdym wyznawcy Chrystusa: „Albowiem jak Syn posłany został przez Ojca, tak i sam posłał Apostołów mówiąc im »idąc tedy nauczajcie wszystkie narody, chrzcząc je w imię Ojca i Syna i Ducha Swiętego, nauczając je zachowywać wszystko, cokolwiek wam przykazałem. A oto ja jestem z wami po wszystkie dni aż do skończenia świata «. Ten uroczysty nakaz Chrystusowy zwiastowania zbawiennej prawdy Kościół otrzymał od Apostołów, aby go wypełnić aż po krańce ziemi... Głosząc Ewangelię, Kościół zachęca słuchających do wierzenia i wyznawania wiary, przygotowuje

1 Relatio finalis, zakończenie, „L'Osservatore Romano", 10 XII 1985, Dodatek w języku łacińskim.

$2 \mathrm{~W}$ pokodeksowej polskiej literaturze kanonistycznej ukazały się na ten temat: E. Szt afrow ski, Misyjna działalnośc Koscioła [w:] Podręcznik Prawa Kanonicznego, t. III, Warszawa 1985, s. 42-51; W. Góralski, Działalność misyjna Kościoła w nowym Kodeksie Prawa Kanonicznego, „Prawo Kanoniczne”, 28 (1985), nr 3-4, s. 33-39; Tenże, Misyjna działalność Kościoła, [w:] Komentarz do Kodeksu Prawa Kanonicznego, t. III, Lublin 1986, s. 28-33. 
ich do chrztu, wyrywa z niewoli błędu i wciela w Chrystusa, aby przez miłość ku niemu dorastali do pełności. Działalnością swoją sprawıa, że cokolwiek dobrego znajduje się zasiane w sercach i umysłach ludzkich, lub we własnych obrządkach i kulturze narodów, wszystko to nie tylko nie ginie, lecz doznaje ulepszenia, wyniesienia na wyższy poziom i pełnego udoskonalenia na chwałę Bożą, na zawstydzenie szatana i na szczęście człowieka. Ze swej strony każdy uczeń Chrystusa ma obowiązek szerzenia wiary" 3 .

Działalność misyjna Kościoła ma wymiar wewnętrzny (jest prowadzona wśród narodów, które już zetknęły się z Ewangelią) a także zewnętrznie skierowana jest do narodów jeszcze nie znających Ewangelii ${ }^{4}$. Zewnętrzna działalność misyjna Kościoła jest nazwana w dokumentach kościelnych „misjami” i oznacza ona głoszenie Ewangelii i zakładanie Kościoła wśród narodów lub grup społecznych jeszcze nie znających Chrystusa: „Ogólnie misjami nazywa się specjalne przedsięwzięcia, które wysłani przez Kościół głosiciele Ewangelii idąc na cały świat, podejmują celem wykonywania zadań głoszenia Ewangelii i zakładania Kościoła wśród narodów lub grup społecznych jeszcze nie wierzących w Chrystusa; dochodzą one do skutku przez działalność misyjną, a przeważnie prowadzi się je na pewnych terenach uznanych przez Stolicę Apostolską. Właściwym celem tej działalności misyjnej jest przepowiadanie Ewangelii i zakładanie Kościoła wśród ludów i grup, gdzie Kościół nie zapuścił jeszcze korzeni" "5. Stąd działalność misyjna ma za zadanie zapoznać narody nieznające Chrystusa z Jego nauką i zorganizować tam nowe Kościoły partykularne, tak aby same mogły prowadzić dzieło ewangelizacji. Dlatego punktem docelowym dzieła misyjnego jest ukonstytuowanie samodzielnych i samowystarczalnych Kościołów partykularnych. O tak pojętej działalności misyjnej naucza dekret „Ad gentes divinitus” i tak ją określa Kodeks Prawa Kanonicznego: „Działalność misyjna we właściwym tego słowa znaczeniu to ta, dzięki której zaszczepia się Kościół w narodach i wspólnotach, w których jeszcze się nie zakorzenil. Jest prowadzona przez Kościół zwłaszcza poprzez wysyłanie zwiastunów Ewangelii, dopóki nowe Kościoły nie zostaną $w$ pełni ukonstytuowane, a więc wyposażone we własne siły i wystarczające pomoce, dzięki czemu będą mogły prowadzić same dzieło ewangelizacji" (kan. 786).

Działalność misyjna zmierzająca do utworzenia na terenach misyjnych stałej organizacji kościelnej jest przedmiotem troski całego Ludu Bożego, który posiada misyjną naturę: „Kościól pielgrzymujący jest mi-

s Konstytucja dogmatyczna Lumen Gentium, nr 17.

1 Por. E. Sztafrowski, Podręcznik Prawa Kanonicznego, t. III, Warszawa 1986 , s. 42.

5 Dekret soborowy Ad gentes divinitus, n. 6. 
syjny ze swej natury, ponieważ swój początek bierze wedle planu Ojca z posłania (ex missione) Syna i z posłania Ducha Swiętego" ". Aktywne zaangażowanie się $\mathrm{w}$ dzieło misyjne jest fundamentalnym obowiązkiem każdego członka Kościoła. Żaden z tych, którzy przyjęli sakrament chrztu i bierzmowania, nie może się wymówić od odpowiedzialności za rozwój Kościoła poprzez misje i ma obowiązek wnosić w nie własny wkład, ma zaznaczyć swój osobisty udział. Kodeks nakazuje wszystkim członkom Kościoła udział w jego dziele misyjnym: „Ponieważ cały Kościół jest ze swej natury misyjny a dzieło ewangelizacji winno być uznane za fundamentalny obowiązek Ludu Bożego, stąd wszyscy wierni, świadomi swej odpowiedzialności, winni wnosić swój udział w dzieło misyjne" (kan. 781). Teologiczną podstawą współpracy misyjnej całego Ludu Bożego jest fakt przynależności przez chrzest do Chrystusa i do Jego Ciała Mistycznego. Związek z Chrystusem i Jego Ciałem Mistycznym, nawiązany przez chrzest i potęgowany przez inne święte sakramenty, zobowiązuje chrześcijanina do pracy nad rozwojem i ustawicznym wzrostem Kościoła ${ }^{7}$. Ta praca obejmować będzie różne funkcje. Podobnie jak dzieło ewangelizacji ciążące na wszystkich ochrzczonych, jest przez nich wykonywane w różny sposób, tak i realizowanie zadania misyjnego będzie spełniane różnorodnie $^{8}$. Wspólnota Ludu Bożego, charakteryzująca się różnorodnością posług, funkcji i stanów, realizuje swój fundamentalny obowiązek działalności misyjnej tak, że każdy jej członek na swój sposób uczestniczy w dziele misyjnym. Ta różnorodność, stanowiąca bogactwo wspólnoty Ludu Bożego, jest przyczyną jego wzrostu i rozwoju. Stąd każdy ochrzczony, w dostępny sobie sposób, jest zobowiązany przyczynić się do wzrostu Kościoła.

\section{UDZIAE WIERNYCH W MISYJNEJ DZIAEALNOSCI KOSCIOEA}

Wśród wiernych, którzy ponoszą szczególną odpowiedzialność za dzieło misyjne Ludu Bożego Sobór wymienia Kolegium Biskupów, któremu przewodzi następca Piotra. Im powierzył Chrystus funkcje kierowania Ludem Bożym, aby ten szerzył się wśród wszystkich narodów świata. Sobór uroczyście przypomniał, że kierowanie dziełem misyjnym Kościoła jest powierzone całemu Kolegium Biskupów pod przewodnictwem Papieża ${ }^{9}$. Kierowniczą funkcję Kolegium Biskupiego w zakresie misyjnej dzia-

6 Tamże, n. 1.

7 Por. W. Góralski, Dziatalność misyjna Kościoła w nowym Kodeksie Prawa Kanonicznego, „Prawo Kanoniczne”, 28 (1985), $\mathrm{nr} 3-4$, s. 34.

8 Por. D. Composta, L'azione missionaria della Chiesa, [w.] Commento al Codice di Diritto Canonico (pod red. P. Pinto), Rzym 1985, s. 480.

9 Konstytucja dogmatyczna Lument gentium, n. 23, 3, por. Dekret soborowy Ad gentes divinitus, n. 6, 1, n. 29. 1.

28 - Analecta Cracoviensia 
łalności Kościoła precyzuje Kodeks w sposób następujący: „Najwyższe kierownictwo oraz koordynacja poczynań i działań związanych z dziełem misyjnym i współpracą misjonarską należy do biskupa rzymskiego oraz Kolegium Biskupów" (kan. 782, § 1).

Ustawodawstwo posoborowe, idąc po linii wytycznych Soboru Watykańskiego II, powołało nowy organ o charakterze kolegialnym zwany Synodem Biskupów ${ }^{10}$. Synod Biskupów, będący niejako reprezentantem Kolegium Biskupów, został wezwany przez Sobór do podjęcia spraw misyjnych: „Niech Synod Biskupów uwzględni wśród spraw o ogólnym znaczeniu w szczególny sposób sprawę działalności misyjnej, jako najważniejszego i najświętszego zadania Kościoła" "11. Synod Biskupów już w 1974 r., omawiając zagadnienie ewangelizacji w świecie współczesnym, podkreślił odpowiedzialność wszystkich biskupów za szukanie nowych, skutecznych form głoszenia Ewangelii tym, którzy wyznają religie niechrześcijańskie: „To głoszenie słowa odnosi się też do tej olbrzymiej liczby ludzi, którzy wyznają religie niechrześcijańskie. Kościół szanuje i ceni wielce te religie niechrześcijańskie, które są znamiennym wyrazem ducha bardzo wielu grup ludzkich; w nich bowiem przejawia się echo głosów tych, którzy przez tysiące lat szukali Boga... Ani wielki szacunek dla tych religii, ani złożoność podnoszonych problemów nie skłaniają Kościoła do zamilczenia przed niechrześcijanami orędzia Jezusa Chrystusa. Przeciwnie, Kościół mniema, że te rzesze mają prawo do poznania bogactw tajemnicy Chrystusa..." 12

Wskazania Soboru wyznaczają także zadania innym kolegialnym organom, jakimi są Konferencje Biskupie. Mają one wspólnymi siłami tworzyć instytucje takie jak seminaria, szkoły wyższe i techniczne, ośrodki duszpasterskie, katechetyczne i teologiczne oraz ośrodki społecznego przekazywania myśli nastawione na niesienie pomocy misjom. Winny one również ustalić określoną składkę, którą każda diecezja ma w miarę swoich możliwości przekazać na dzieło misyjne, oraz skierować z poszczególnych diecezji kapłanów do pracy $\mathrm{w}$ dziele ewangelizacji $\mathrm{w}$ krajach misyjnych ${ }^{18}$. Kodeks Prawa Kanonicznego zaleca ponadto Konferencjom Biskupim troskę o osoby przybywające $\mathrm{z}$ terenów misyjnych do krajów tradycyjnie chrześcijańskich: „Konferencje Episkopatu powinny inicjować i popierać poczynania, dzięki którym osoby, przybywające z terenów misyjnych dla podjęcia prac lub odbycia studiów, doznawałyby braterskiego przyjęcia i wsparcia" (kan. 792). Dekret o działalności misyjnej Kościoła zwraca

10 Papież Paweł VI, Motu proprio Apostolica sollicitudo 15 IX 1965, AAS 57 (1965), s. $755-800$.

${ }^{11}$ Dekret soborowy Ad gentes divinitus, n. 31 .

12 Papież Paweł VI, Adhortacja apostolska Evangelii nuntiandi, AAS 58 (1976), s. $41-42$.

18 Por. Dekret soborowy Ad gentes divinitus, n. 31, n. 38.5. 
uwagę na obowiązki, jakie spoczywają na Konferencjach Biskupich utworzonych na terenach misyjnych. Winny one troszczyć się o to, aby kler wśród różnorodnych i zmieniających się warunków zdobywał coraz gruntowniejszą wiedzę teologiczną i znajomość właściwych metod duszpasterskich. W tym celu należy organizować kursy odnowy biblijnej, teologicznej, ascetycznej i pastoralnej. Mają one zainteresować się przygotowaniem odpowiedniej liczby szafarzy do pracy w poszczególnych Kościołach swojego rejonu, jak również zorganizować wysyłanie od siebie misjonarzy do głoszenia Ewangelii w innych krajach świata. Konferencje Biskupie terenów misyjnych mają ustalić zasady dialogu ze społecznościami cywilnymi swoich terenów, a następnie nim pokierować. Zadaniem ich będzie także przygotowanie i zrealizowanie ,planu przystosowania”. Polega on na uwypukleniu i uwzględnieniu tych miejscowych zwyczajów, tradycji wiedzy, sztuki, umiejętności i wartości, które ułatwią zakorzenienie się Ewangelii i Kościoła na nowym terenie. Chodzi o to, aby wykluczyć synkretyzm i fałszywy partykularyzm, a życie chrześcijańskie dostosować do ducha i charakteru poszczególnych kultur, a partykularne tradycje wraz z cechami właściwymi poszczególnym ludom przepoić światłem Ewangelii i przyjąć do katolickiej jedności ${ }^{14}$. Ewangelizacja poszczególnych ludów ma uwzględnić ich prawdziwe wartości kulturowe, ich godziwe tradycje i zwyczaje oraz wciągnąc je w służbę Ewangelii. Obowiązek rozeznania, dostosowania i przejęcia prawdziwego bogactwa społeczno-kulturowego ewangelizowanych narodów spoczywa na ich Konferencjach Biskupów.

Dokumenty kościelne określają rolę poszczególnych biskupów w dziele misyjnym. Są oni zobowiązani współpracować z Papieżem i wzajemnie ze sobą w szerzeniu Ewangelii: „Toteż poszczególni biskupi, o ile im na to pozwala wykonywanie własnego urzędu, obowiązani są współpracować wzajemnie ze sobą i następcą Piotra, któremu w sposób szczególny został powierzony wzniosły urząd szerzenia imienia chrześcijańskiego. Dlatego też powinni usilnie dostarczać misjom tak żniwiarzy, jak i pomocy duchowych i materialnych, zarówno sami bezpośrednio jak i wzbudzając żarliwą współpracę wiernych” ${ }^{15}$. „Biskup w swej diecezji, z którą stanowi jedno, wzbudzając dzieło misyjne, popierając i kierując nim, sprawia, że duch i zapał misyjny Ludu Bożego obleka się w ciało i niejako uwidacznia, tak że cała diecezja staje się misjonarską" ${ }^{16}$. Do ważnych obowiązków biskupa należeć będzie organizowanie pomocy duchowej dla misji w formie modlitwy i pokuty, popieranie powołań misyjnych, wspomaganie stowarzyszeń i instytutów misyjnych oraz troska o „Papieskie Dzieła Misyjne". Biskupi winni wysyłać niektórych swych lepszych kapłanów,

\footnotetext{
14 Por. Dekret soborowy Ad gentes divinitus, n. 22.

15 Konstytucja dogmatyczna Lumen gentium, n. 23, 3.

16 Dekret soborowy Ad gentes divinitus, n. 38, 2.
} 
po odpowiednim przygotowaniu do pracy $\mathrm{w}$ dziele misyjnym ${ }^{17}$. Biskup diecezji misyjnej zobowiązany jest do popierania, kierowania i uzgadniania działalności misyjnej, tak jednak, aby zachować i rozwijać inicjatywę tych, którzy uczestniczą $\mathrm{w}$ tym dziele. W wykonywaniu świętego apostolstwa wszyscy misjonarze podlegają jego władzy. Ma postarać się, by praca apostolska była skierowana nie tylko do już nawróconych, ale także, by objęła swym zasięgiem niechrześcijan. Celem lepszej współpracy ma on ustanowić Radę Duszpasterską, składającą się z wybranych delegatów, duchownych, zakonników i świeckich ${ }^{18}$. Kodeks postanawia, że do biskupa diecezjalnego na terytoriach misyjnych należy:

a. inicjować, kierować i koordynować wszystkie poczynania i dzieła misyjne;

b. czuwać nad tym, by zostały zawarte odpowiednie umowy z przełożonymi Instytutów oddalających się pracy misyjnej, z korzyścią dla misji;

c. przepisy wydane przez niego a dotyczące działalności misyjnej obowiązują wszystkich misjonarzy (por. kan. 790).

Zatem biskupowi diecezji misyjnej podlega cała działalność misyjna na jej terenie, oraz wszyscy misjonarze ją prowadzący. Natomiast biskupów poszczególnych diecezji zobowiązuje Kodeks do umacniania współpracy misyjnej poprzez:

a. popieranie powołań misyjnych;

b. wyznaczenie kapłana zajmującego się skutecznym organizowaniem pomocy misyjnej, a zwłaszcza sprawującego opiekę nad Papieskimi Dziełami Misyjnymi;

c. zorganizowanie dorocznego dnia misyjnego;

d. przesłanie corocznej ofiary na rzecz misji za pośrednictwem Stolicy Apostolskiej (por. kan. 791).

Dekret o działalności misyjnej Kościoła wyznacza także w niej zadania kapłanom, zarówno wywodzącym się z terenów misyjnych jak i z krajów tradycyjnie chrześcijańskich ${ }^{19}$. Kapłani będący zastępcami Chrystusa i współpracownikami biskupów powinni jasno uświadomić sobie, że ich życie jest również poświęcone na służbę misjom. Toteż tak mają prowadzić pracę duszpasterską, aby mogła służyć ewangelizacji świata. Szczególnie winni ukazywać rodzinom chrześcijańskim konieczność i zaszczyt pielęgnowania powołań misyjnych wśród swych synów i córek, a młodzież szkolną wychowywać w zapale misyjnym, aby z nich wyrośli przyszli zwiastunowie Ewangelii. Mają oni uczyć wiernych modlić się w intencji misji i prosić ich o jałmużnę na rzecz misji. Do szczególnej gorli-

17 Por. tamże, n. $38,3-4$.

18 Por. tamże, n. 30.

19 Por. tamże, n. 39. 
wości wzywa Sobór kapłanów pochodzących z ludów niedawno nawróconych do Chrystusa: „Niech w młodych Kościołach kapłani miejscowego pochodzenia przystąpią z zapałem do głoszenia Ewangelii, ściśle współpracując z misjonarzami przybyłymi z zagranicy; niech tworzą z nimi jedno kolegium kapłańskie, zespolone pod kierownictwem biskupa nie tylko dla opieki duszpasterskiej nad wiernymi i sprawowania służby Bożej, lecz także celem głoszenia Ewangelii tym, którzy są poza Kościołem" ${ }^{20}$. Wielką wagę przywiązuje nauczanie soborowe do należytej formacji intelektualnej, teologicznej, ascetycznej i pastoralnej alumnów w seminariach zakładanych w młodych Kościołach. Oprócz formacji kapłańskiej należy umysły i serca alumnów otworzyć i uwrażliwić na kulturę, tradycje ojczyste, historię i warunki społeczno-ekonomiczne własnego narodu, aby je umieli właściwie ocenić i wartościować ${ }^{21}$.

Wielorakie zadania w dziele misyjnym wyznacza Sobór instytutom zakonnym. Instytuty poświęcone kontemplacji mają przez swoje modlitwy, pokutne uczynki i cierpienia przyczyniać się do otwierania serc niechrześcijan na głos Ewangelii i do wypraszania nowych zastępów misjonarzy. W miarę możliwości wzywa się te zakony, aby zakładały swe domy na terenach misyjnych. Instytuty oddane apostolstwu czynnemu winny rozciągnąc swą działalność ewangelizacyjną wśród narodów nie znających Ewangelii. W tym celu więcej uwagi mają poświęcić pracy misyjnej dostosowując do tego w razie potrzeby swoje konstytucje ${ }^{22}$. Na terenach misyjnych należy pielęgnować różne formy życia zakonnego, aby w ten sposób ukazać bogactwo życia Kościoła i różnorodność misji Chrystusa. W organizowaniu życia zakonnego należne miejsce należy przyznać życiu kontemplacyjnemu, wykorzystując elementy ascetyczne i kontemplatywne zawarte w tradycjach poszczególnych narodów. Bogate zakonne tradycje Kościoła należy przeszczepić na nowy grunt uwzględniając i wykorzystując usposobienie i tradycje poszczególnych narodów. Warunkiem należytego rozwoju różnych zakonów w młodych kościołach jest ich wzajemna współpraca, jak również współdziałanie z miejscową hierarchią ${ }^{23}$. W oparciu o wskazania Soboru, Kongregacja Ewangelizowania Narodów opracowała instrukcję ustalającą pewne zasady i normy dotyczące stosunków między ordynariuszami miejsca a instytutami misyjnymi ${ }^{24}$. Przewodnią ideą przytoczonej instrukcji jest wspólna służba ewangelizacji w krajach misyjnych. Nie ulega wątpliwości, że udział instytutów zakonnych w dziele misyjnym ma znaczenie decydujące. Wiele zakonów i zgromadzeń zostało specjalnie założonych w tym celu, aby poświęcić się pracy

20 Tamże, n. 20, 3.

21 Tamże, n. 16.

22 Por. tamże, n. 40.

23 Por. tamże, œ. 18, n. 33.

24 AAS 61 (1969), s. 24 II 1969. 
misyjnej. Aktualnie, mimo że cały Lud Boży ponosi odpowiedzialność za misje, rola zakonów jest niezastąpiona. Toteż zarówno Sobór jak i dokumenty posoborowe poświęcają tej sprawie wiele uwagi. Kodeks Prawa Kanonicznego w krótkiej normie streszcza niejako zadania misyjne zakonów: „Ponieważ członkowie instytutów życia konsekrowanego na mocy samej konsekracji poświęcają się na służbę Kościołowi, powinni w sposób właściwy ich instytutowi mieć szczególny udział w działalności misyjnej" (kan. 783). Przytoczony kanon podaje uzasadnienie szczególnej roli zakonów $\mathrm{w}$ dziele misyjnym. Jest to wyłączne poświęcenie się przez konsekrację zakonną na służbę Kościołowi i wypływająca stąd szczególna odpowiedzialność za jego rozwój oraz za jego rozszerzanie się po całej ziemi.

Zgodnie z nauczaniem Soboru w działalności misyjnej nie może zabraknąć wiernych świeckich. Swieccy w krajach już chrześcijańskich współpracują $\mathrm{w}$ dziele ewangelizacji świata, pielęgnując $\mathrm{w}$ sobie oraz $\mathrm{w}$ innych znajomość i umiłowanie misji, troszcząc się o powołanie misyjne we własnej rodzinie, w zrzeszeniach katolickich i w szkołach. Niektórzy świeccy powołani przez Boga i przyjęci przez biskupa bywają bezpośrednio zaangażowani do pracy $w$ krajach misyjnych. Swieccy na terenach misyjnych, zarówno przybysze jak i tubylcy, mogą podjąć różne formy apostolstwa świeckich, takie, jak nauczanie w szkołach, prowadzenie spraw gospodarczych, współpraca $\mathrm{w}$ działalności parafii i diecezji ${ }^{25}$. Ukształtowanie dojrzałego chrześcijańskiego laikatu jest przedmiotem najpilniejszej troski w pracy misyjnej, jak również jest miarą zakorzenienia się Ewangelii: „Kościół nie jest naprawdę założony, nie żyje w pełni ani też nie jest doskonałym znakiem Chrystusa wśród ludzi, jeżeli wraz z hierarchią nie istnieje i nie pracuje autentyczny laikat. Ewangelia bowiem nie może zapuścić głębokich korzeni w umysłach, w życiu i pracy jakiegoś narodu bez czynnego udziału ludzi świeckich. Dlatego już przy zakładaniu Kościoła należy przywiązywać jak największą wagę do tworzenia dojrzałego chrześcijańskiego laikatu" ${ }^{26}$. Nie ulega wątpliwości, że działalnością misyjną winna kierować hierarchia, ale jej działanie będzie tylko wtedy skuteczne, jeśli podejmie współpracę z katolikami świeckimi. Należycie przygotowany laikat jest gwarantem stabilizacji życia kościelnego na terenach misyjnych, jak i warunkiem kontynuowania ewangelizacji wśród innych narodów ${ }^{27}$.

Wśród świeckich szczególną rolę w dziele misyjnym spełniają katechiści: „Również godnym pochwały jest ów zastęp tak bardzo zasłużonych

${ }_{25}$ P.or. Dekret soborowy Ad gentes divinitus, n. 41.

28 Tamże, n. 21, 1.

27 Por. J. G. Martin, Los laicos en las missiones, "Monitor ecclesiasticus", 108 (1983), s. $110-112$. 
w dziele misyjnym, mianowicie zastęp katechistów, mężczyzn i niewiast, którzy pełni apostolskiego ducha są dzięki swej wybitnej pracy szczególną i wręcz nieodzowną pomocą przy rozszerzaniu wiary i Kościoła" ${ }^{28}$. Dekret soborowy szeroko omawia zadania i przygotowanie katechistów. $\mathrm{W}$ oparciu o te wskazania $\mathrm{w}$ wielu krajach misyjnych ukazały się szczegółowe przepisy regulujące sprawę przygotowania i spełniania swoich funkcji przez katechistów. Także nowy Kodeks podkreśla znaczenie ich posługi: „§ 1. Do realizacji dzieła misyjnego powinni być angażowani katechiści, a więc wierni świeccy odpowiednio przygotowani i wyróżniający się życiem chrześcijańskim. Pod kierownictwem misjonarza zajmują się oni przekazywaniem nauki ewangelicznej, organizowaniem życia liturgicznego i prowadzeniem akcji charytatywnej.

$\S 2$. Katechiści winni otrzymać formację w przeznaczonych do tego szkołach, a gdy takich nie ma, pod kierunkiem misjonarzy" (kan. 985). Tak więc Kodeks postanawia, aby w pracę misyjną bezpośrednio zaangażować wiernych świeckich w charakterze katechistów, którzy mają stanowić wydatną pomoc dla kapłanów, a w wypadku ich braku mogą podjąc wiele funkcji, związanych ze spełnianiem potrójnej posługi Kościoła, posługi nauczania, uświęcania i pasterzowania, wyjąwszy oczywiście te funkcje, które wyłącznie przysługują kapłanowi. Dla przykładu Kodeks wymienia katechistę jako szafarza chrztu w razie nieobecności szafarza zwyczajnego (por. kan. 861 § 2). Prawodawca stawia katechiście szczególne wymagania, mianowicie należyte przygotowanie, a zwłaszcza wyróżniające się życie chrześcijańskie. Żąda zatem, aby katechista był szczególnym świadkiem Ewangelii.

Powiedzieliśmy wyżej, że zgodnie $\mathrm{z}$ nauką Soboru cała wspólnota Ludu Bożego jest odpowiedzialna za działalność misyjną. Jej członkowie mają różne zadania misyjne do spełnienia. Wśród nich szczególna rola przypada tym, których nazywamy misjonarzami. Dekret soborowy „Ad gentes divinitus" poświęca sprawie misjonarzy cały rozdział IV. Wyraźnie akcentuje się tam, że misjonarzem może być tylko ten, kto został do tego powołany przez Boga i przez kompetentną władzę kościelną. Powołanie misyjne to szczególna łaska wybrania Chrystusowego, którą obdarza on kapłanów, osoby zakonne i świeckich: „Specjalnym bowiem powołaniem naznaczeni są ci, którzy obdarzeni odpowiednimi naturalnymi właściwościami, przymiotami serca i umysłu gotowi są podjąć dzieło misyjne, obojętnie czy to będą miejscowi czy też obcy, kapłani, osoby zakonne i ludzie świeccy" ${ }^{29}$. Człowiek obdarzony darem powołania misyjnego zobowiązany jest należycie się przygotować, aby następnie swoim życiem i słowem głosić Ewangelię oraz ukazywać Chrystusa i być Jego

28 Dekret soborowy Ad gentes divinitus, n. 17, 1 .

29 Tamże, n. 23, 2. 
świadkiem. Do soborowego określenia misjonarza nawiązuje nowy Kodeks: „Misjonarze, a więc ci, którzy są posłani przez kompetentną władzę kościelną do podejmowania dzieła misyjnego, mogą być dobierani z terenów misyjnych lub spoza nich, spośród kleru diecezjalnego lub członków instytutów życia konsekrowanego, albo stowarzyszeń życia apostolskiego, albo spośród świeckich" (kan. 784). Przytoczone określenie słusznie podkreśla potrzebę upoważnienia przez władzę kościelną do prowadzenia działalności misyjnej, która jest w ścisłym znaczeniu działalnością Kościoła. Nie może zatem być prowadzona w imieniu jakiejś osoby czy grupy, lecz w imieniu Kościoła. Słusznie również zaznaczono, że misjonarze winni się rekrutować zarówno z terenów misyjnych, jak i krajów tradycyjnie chrześcijańskich. $\mathrm{Na}$ uwagę zasługuje przyznanie tytułu „misjonarza” ludziom świeckim i zrównanie ich $\mathrm{w}$ tej funkcji $\mathrm{z}$ duchownymi i zakonnikami. Oczywiście nie zmienia to faktu, że posługa misjonarska świeckich skierowana jest tylko do tych zadań, które z racji przyjętego sakramentu chrztu i bierzmowania mogą wypełniać. Otrzymany przez nich od władzy kościelnej mandat nie upoważnia ich do wykonywania czynności wymagających święceń. Pewnym mankamentem kodeksowego określenia „misjonarza” jest pominięcie faktu szczególnego wezwania Bożego do działalności misyjnej, bowiem ono stanowi podstawę oraz prawo, a zarazem obowiązek podjęcia dzieła misyjnego.

Zgodnie z nauczaniem Soboru, skonkretyzowanym w normach prawnych prawodawstwa posoborowego łącznie z nowym Kodeksem, cały Lud Boży jest wezwany do dzieła misyjnego, ma w nim do spełnienia swoją rolę. Szeroki zakres działalności misyjnej Kościoła sprawia, że wspólnota wiernych zobowiązana jest do różnych funkcji i posług misyjnych. Szczególne zadania ciążą na tych, którzy zostali obdarowani powołaniem misyjnym i posłani przez kompetentną władzę kościelną do bezpośredniej pracy misyjnej. Otrzymany dar Bożego wezwania zobowiązuje obdarowanych i nakłada na nich obowiązek wierności powołaniu misyjnemu.

\section{ORGANIZACJA DZIAŁALNOŚCI MISYJNEJ KOSCIOŁA}

Kongregacja Ewangelizowania Narodów czyli Rozkrzewiania Wiary

Sobór Watykański II przypomniał prawdę o konieczności należytej organizacji działalności misyjnej: ,Dlatego pracą głosicieli Ewangelii i pomocą innych wiernych należy tak pokierować i tak je zespolić, aby na każdym polu działalności i współpracy misyjnej, wszystko odbywało się w należytym porządku" " ${ }^{30}$. Całą działalnością misyjną Kościoła w świe-

30 Dekret soborowy Ad gentes divinitus, n. 28, 2. 
cie kieruje Kongregacja Ewangelizowania Narodów. Ma ona organizować oraz koordynować wszystkie poczynania i inicjatywy misyjne. Ma układać plan pracy ewangelizacyjnej, podawać miarodajne wskazówki, zbierać, przechowywać i przekazywać informacje, gromadzić oraz rozprowadzać środki materialne, popierać powołania misyjne, umiejętnie rozsyłać misjonarzy i organizować współpracę $\mathrm{w}$ krajach misyjnych. Kongregacja ta winna być narzędziem administracji, jak i organem dynamicznego kierownictwa, posługującym się naukowymi metodami i uwzględniającym współczesne badania w dziedzinie teologii, metodologii i duszpasterstwa misyjnego. W kierowaniu Kongregacją winni uczestniczyć, z głosem decydującym, przedstawiciele biskupów z całego świata, jak również winna ona posiadać zespół fachowych doradców należycie przygotowanych i doświadczonych, pochodzących $\mathrm{z}$ różnych krajów ${ }^{31}$. W oparciu o powyższe wytyczne Soboru prawodawstwo posoborowe dokonało gruntownej reformy omawianej Kongregacji ${ }^{32}$. Wśród dokumentów tegoż prawodawstwa zasadnicze znaczenie posiada Konstytucja apostolska Regimini Ecclesiae Universae z 15 sierpnia 1967 r., która dokonała odnowy Kurii Rzymskiej ${ }^{33}$. Przytoczona Konstytucja zmieniła nazwę dotychczasowej Kongregacji Rozkrzewiania Wiary na Kongregację Ewangelizowania Narodów czyli Rozkrzewiania Wiary. Do jej kompetencji należą sprawy wszystkich misji, prowadzonych dla rozszerzania Kościoła, a więc powoływanie i zmienianie zatrudnionych tam osób, ustalania granic kościelnych jednostek administracyjnych i przedstawianie osób, które by nimi kierowały. Ma ona troszczyć się o zwiększanie się liczby miejscowego duchowieństwa, o jego należytą formację, jak również o przekazywanie mu stopniowo ważniejszych i kierowniczych funkcji. Jest odpowiedzialna za kierowanie i planowanie działalności misyjnej na całym świecie, dotyczące zarówno misjonarzy, jak i współpracy oraz zaangażowania wiernych.

Kongregacji przewodniczy kardynał prefekt, mając do pomocy sekretarza i podsekretarza. W jej skład wchodzą kardynałowie i inni członkowie mianowani przez papieża. Papież mianuje jako członków Kongregacji 24 przedstawicieli z całego Kościoła, w tym 12 prałatów z terenów misyjnych, $4 \mathrm{z}$ innych terytoriów, 4 spośród najwyższych przełożonych zakonnych instytutów kleryckich, posiadających udział w misyjnej działalności Kościoła oraz 4 z Papieskich Dzieł Misyjnych. Do grona członków wchodzą także z urzędu: przewodniczący Sekretariatu Jedności Chrześcijan, Sekretariatu dla Spraw Niechrześcijan i Sekretariatu dla Spraw Niewierzących. W pracach Kongregacji uczestniczy zespół konsultorów.

31 Tamże, n. 29, 5.

32 Szerzej na ten temat: por. E. Sztafrowski, Kuria Rzymska, Warszawa 1981 , s. $144-165$ oraz R. Skow ron e k, Kongregacja Ewangelizowania Narodów w rozwoju historyczno-prawnym, ,Prawo Kanoniczne", 16(1973) mr 3-4, s. 191-207. 33 AAS 59 (1967), s. 885-928. 
Mogą do niego należeć biskupi, kapłani, zakonnicy, zakonnice oraz świeccy, zarówno mężczyźni jak i kobiety. Muszą się odznaczać biegłością w sprawach misyjnych, roztropnością i odpowiednim doświadczeniem. Są oni mianowani przez papieża na pięć lat. Oprócz nich do zespołu konsultorów należą z urzędu inne osoby na zasadzie spełnianych funkcji. $\mathrm{Na}$ przykład sekretarze: Sekretariatu Jedności Crześcijan, Sekretariatu dla Spraw Niechrześcijan i Sekretariatu dla Spraw Niewierzących ${ }^{34}$. Do szczególnych zadań Kongregacji Ewangelizowania Narodów należy kierowanie i opieka nad Papieskimi Dziełami Misyjnymi.

\section{Papieskie Dzieła Misyjne}

Sobór Watykański II nawołuje do popierania Papieskich Dzieł Misyjnych, gdyż spełniają one niezastąpioną rolę w działalności misyjnej Kościoła: „Tym dziełom bowiem słusznie należy się pierwszeństwo, ponieważ są środkiem tak do wpajania katolikom od dzieciństwa ducha prawdziwie powszechnego i misyjnego, jak i do pobudzania do skutecznego zbierania dobrowolnych ofiar na rzecz wszystkich misji, zależnie od ich potrzeb",35.

Papieskie Dzieła Misyjne tworzą jedną instytucję, składającą się z czterech organów:

Papieskie Dzieło Misyjne Rokrzewiania Wiary,

Papieskie Dzieło Misyjne Św. Piotra Apostoła,

Papieskie Dzieło Misyjne Świętego Dziecięctwa lub Dziecięctwa Misyjnego

Papieska Unia Misyjna.

Dzieła te mają za cel budzenie i pogłębianie świadomości Ludu Bożego, dostarczanie informacji o stanie i potrzebach misji na wszystkich kontynentach, zachęcanie do wzajemnej pomocy duchowej i materialnej, użyczanie pracowników misyjnych, budzenie ducha solidarności w ewangelizowaniu świata. Są one świadectwem katolickości Kościoła, będąc bowiem dziełami papieża są zarazem dziełami całego Kolegium Biskupiego i całego Ludu Bożego. Są one także uprzywilejowanym środkiem w utrzymywaniu łączności zarówno między poszczególnymi Kościołami partykularnymi, jak i między każdym z nich a papieżem ${ }^{36}$. Zasadniczym zadaniem Papieskich Dzieł Misyjnych jest ewangelizacja. Nie wyklucza to jednak wielorakiej pomocy, jaką niosą one Kościołom uboższym. Chodzi

34 Por. Konstytucja Apostolska Regimini Ecclesiae Universae, n. 81-90: AAS 59(1967), s. 915-918; por. Instrukcja Kongregacji Ewangelizowania Narodów w sprawie dotaczania członków $i$ konsultorów do tejże Kongregacji, PPK, t. VII, z. 1, n. $12939-12964$.

${ }^{35}$ Dekret soborowy Ad gentes divinitus, n. 38, 3.

${ }^{38}$ Kongregacja Ewangelizowania Narodó, Statuty Papieskich Dziet Misyjnych, 26 VI 1980, Rozdzial I, n. 1-6, wyd. broszurowe. 
tu o różnorodną pomoc charytatywną, społeczną, ekonomiczną, leczniczą itd. Toteż służą one integralnemu rozwojowi narodów. Niosąc pomoc młodym Kościołom okazują im należny szacunek i zachęcają je do podejmowania działań prowadzących do stopniowego dojrzewania ku samowystarczalności ${ }^{37}$.

Poszczególne dzieła mają wyznaczone konkretne zadania. Papieskie Dzieło Misyjne Rozkrzewiania Wiary ma budzić zainteresowanie dla powszechnej ewangelizacji we wszystkich ośrodkach życia religijnego, a więc w rodzinach, we wspólnotach podstawowych, w parafiach, w szkołach, w ruchach i organizacjach apostolskich. Dzieło zabiega o stworzenie scentralizowanego funduszu, który jest przeznaczony na zaspokojenie w sposób regularny najbardziej istotnych potrzeb wszystkich Kościołów na terenach misyjnych, a także informuje katolików o ich życiu i potrzebach. Troszczy się także o braterską i solidarną więź między Kościołami, jak również prowadzi akcję wychowawczą, zwłaszcza wśród młodzieży. Papieskie Dzieło Misyjne św. Piotra Apostoła ma za zadanie ogranizowanie przygotowania kandydatów do kapłaństwa, jak również kandydatów i kandydatek do życia zakonnego, wywodzących się z ludności tubylczej. Papieskie Dzieło Misyjne Dziecięctwa Misyjnego ma wspomagać w rozbudzaniu i rozwijaniu u dzieci uniwersalnej świadomości misyjnej i wdrażać je do dzielenia się skarbem wiary i środkami materialnymi z dziećmi krajów i Kościołów uboższych. Dzieło to poprzez swoją działalność wychowawczą i apostolską ma przyczyniać się do rozbudzania nowych powołań misjonarskich. Papieska Unia Misyjna kapłanów, zakonników i zakonnic ma za cel informację i formację misyjną kapłanów, członków instytutów życia konsekrowanego, kandydatów do kapłaństwa i do zakonów. Zwraca się więc ona do wszystkich, którzy z racji swego szczególnego powołania mają inicjować i kierować oraz ożywiać działalność misyjną Kościoła. Unia ma pomagać $\mathrm{w}$ znalezieniu najlepszych metod duszpasterskich $\mathrm{w}$ prowadzeniu uniwersalnego dzieła misyjnego ${ }^{38}$.

\section{Krajowa Komisja do Spraw Misji}

Sobór zaleca Konferencjom Biskupim poszczególnych krajów pokierowanie $\mathrm{w}$ nich sprawami misji i skuteczne zorganizowanie współpracy misyjnej ${ }^{39}$. Nawiązując do tego wskazania normy wykonawcze do dekretu Ad gentes divinitus postanawiają: „Przy Konferencjach Biskupich powinna istnieć Komisja Biskupia dla Misji. Jej zadaniem będzie pobudzanie działalności i świadomości misyjnej oraz harmonijnej współpracy między die-

\footnotetext{
37 Tamże, n. $7-8$.

3s Por. tamże, nr 9-27.

39 Dekret soborowy Ad gentes divinitus, n. 38, 5-6.
} 
cezjami, utrzymywanie kontaktów $\mathrm{z}$ innymi Konferencjami Biskupimi oraz poszukiwanie sposobów celem zachowania, w miarę możności, słuszności w niesieniu pomocy misjom" "40. O obowiązku powołania Komisji do Spraw Misji o zasięgu krajowym wspomina także Instrukcja Kongregacji Ewangelizowania Narodów, z dnia 24 lutego 1969 r., dotycząca ułożenia misyjnej współpracy biskupów z Papieskimi Dziełami Misyjnymi oraz w zakresie inicjatyw poszczególnych diecezji na rzecz misji: „Przy Konferencjach Biskupich winna być powołana specjalna Komisja dla Spraw Misji, jako najważniejszy organ działający na korzyść misji" ${ }^{41}$. Główne zadania tej Komisji są następujące:

a) popieranie poczynań, które budzą wśród Ludu Bożego, a zwłaszcza wśród duchowieństwa, świadomość i aktywność misyjną;

b) popieranie Papieskich Dzieł Misyjnych oraz czuwanie nad przestrzeganiem ich ustaw;

c) przesłanie Konferencji Biskupiej należnej daniny, jaką poszczególne diecezje - proporcjonalnie do swoich możliwości - winny co roku przesłać Kongregacji Ewangelizowania Narodów;

d) czuwanie nad odpowiednią organizacją działalności Konferencji Biskupiej na rzecz misji, by pomagała ona Papieskim Dziełom Misyjnym, jak również innym instytutom i dziełom, erygowanym w danym kraju dla celów misyjnych ${ }^{42}$.

Celem zapewnienia jak najskuteczniejszej współpracy misjonarskiej, jedności działania, Komisja Biskupia dla Spraw Misyjnych winna się posługiwać Krajową Radą Misyjną ${ }^{43}$, którą kieruje przewodniczący tejże Komisji ${ }^{44}$.

W skład Krajowej Rady Misyjnej wchodzą: przewodniczący Papieskiego Stowarzyszenia Kleru Misyjnego, Krajowi Dyrektorzy Papieskich Dzieł Misyjnych, a także niektórzy inni kapłani, jak również delegaci diecezjalni wybrani przez Komisję Biskupią, delegaci Instytutów Misyjnych, działających na terenie danego kraju oraz delegaci stowarzyszeń świeckich świadczących pomoc na rzecz misji ${ }^{45}$. Skuteczne działanie Krajowej Komisji zależne jest także od jej współpracy z poszczególnymi diecezjami, w których kierowanie działalnością misyjną należy do biskupa. Ma on powołać odpowiednią instytucję lub przynajmniej wyznaczyć kapłana dla opieki nad działalnością misyjną ${ }^{46}$.

Przedstawione wyżej przepisy prawodawstwa powszechnego określają w sposób ramowy strukturę i działanie Krajowej Komisji. Ich skonkre-

\footnotetext{
${ }^{40}$ Mp. Es. III, n. 9; AAS 58(1966), s. 784.

${ }^{41}$ Instrukcja Quo aptius, AAS 61(1969), s. 278.

42 Tamże, s. 278.

43 Mp. E. III, n. 11; AAS 58(1966), s. 784.

${ }^{44}$ Instrukcja Quo aptius, AAS 61(1969), s. 278.

45 Tamże, s. 278.

${ }^{46}$ Por. Dekret soborowy Ad gentes divinitus, n. 30.
} 
tyzowania dokonują statuty i regulaminy wydane przez Konferencje Biskupie. Zobaczmy, jak została ukształtowana struktura Komisji Episkopatu Polski do Spraw Misji i jakie podejmuje działania.

Komisja Episkopatu Polski do Spraw Misji

W myśl wskazań prawodawstwa powszechnego Konferencja Episkopatu Polski utworzyła Komisję do Spraw Misji. Jej zasadniczym celem jest budzenié oraz rozwój świadomości i gorliwości misyjnej wśród wszystkich katolików polskich, popieranie wszelkich inicjatyw podejmowanych na rzecz misji oraz ich koordynowanie dla dobra Kościoła powszechnego i lokalnego.

W szczególności zaś Komisja:

a) ustala aktualne możliwości współpracy Kościoła w Polsce z misjami oraz kieruje organizowaniem sposobów i środków, które wspierają działalność misyjną Kościoła;

b) ułatwia organizowanie i rozwój instytutów misyjnych oraz pobudza i popiera inicjatywy misyjne wśród instytutów zakonnych oraz wśród instytucji kościelnych w Polsce;

c) popiera Papieskie Dzieła Misyjne i inne inicjatywy misyjne;

d) troszczy się o budzenie powołań misyjnych oraz o przygotowanie misjonarzy do ich przyszłej pracy;

e) stara się przyjść z pomocą duchową i materialną tym, którzy przybywają do Polski z terenów misyjnych na studia lub $\mathrm{w}$ innych celach ${ }^{47}$.

Pracami Komisji kieruje przewodniczący wspierany przez wiceprzewodniczącego i sekretarza. W jej skład wchodzą członkowie i urzędu i nominacji, którzy są powoływani przez Konferencję Episkopatu. Członków $\mathrm{z}$ nominacji należy dobierać $\mathrm{w}$ ten sposób, aby reprezentowali:

a) Episkopat Polski (przynajmniej 4 biskupów),

b) Dyrektorów diecezjalnych Papieskich Dzieł Misyjnych,

c) Instytuty Misyjne i Zgromadzenia Zakonne prowadzące działalność misyjną,

d) Inne Komisje Episkopatu, których działalność wiąże się z misjami,

e) Katolików świeckich.

Komisja posiada Radę Komisji składającą się z przewodniczącego, wiceprzewodniczącego, sekretarza i dwóch członków Komisji. Powołuje ich przewodniczący, mogą nimi być także katolicy świeccy ${ }^{48}$. Zgodnie z regu-

${ }^{47}$ Regulamin Komisji Episkopatu Polski do Spraw Misji, n. 4-7, maszynopis (Archiwum Kurii Metropolitalnej w Krakowie).

48 Por. tamże, n. 8-9. 
laminem Komisji Episkopatu Polski do Spraw Misji spełnia ona funkcję Krajowej Rady Misyjnej ${ }^{49}$.

Jedną z ważniejszych dziedzin działania Polskiej Komisji do spraw Misji jest przygotowanie i wysyłanie misjonarzy na tereny misyjne oraz niesienie im pomocy duchowej i materialnej. W tym celu Komisja przygotowała Instrukcję regulującą wyjazdy i pomoc dla kapłanów diecezjalnych na terenach misyjnych, która została zatwierdzona przez Konferencję Plenarną Episkopatu Polski w dniu 22 I 1974 r. ${ }^{50}$ Staraniem Komisji zostało powołane w 1984 r. przez Konferencję Episkopatu Centrum Formacji Misyjnej w Warszawie. Jest ono placówką prowadzącą stałe i systematyczne przygotowanie polskich misjonarzy i misjonarek zamierzających wyjechać do pomocy Kościołom lokalnym w krajach III świata, tj. Afryki, Ameryki Łacińskiej, Azji i Oceanii. W pierwszej fazie swej działalności Centrum jest nastwione na przygotowanie osób duchownych i zakonnych, w następnym etapie także ludzi świeckich. Wydaje się, że aktualnie zachodzi pilna potrzeba zajęcia się przez Komisję do Spraw Misji przygotowaniem i wysyłaniem na tereny misyjne katolików świeckich. Jak wskazuje praktyka, są oni nieocenioną pomocą dla kapłanów misjonarzy. Tym bardziej sprawa jest aktualna obecnie, gdyż Kodeks wzywa wiernych świeckich do podjęcia pracy na terenach misyjnych.

Sobór Watykański II wraz z prawodawstwem posoborowym, łącznie z nowym Kodeksem ukazał misyjny charakter wspólnoty Ludu Bożego. Wyznaczył poszczególnym jej członkom zadania w dziele misyjnym. Podał on także zasady, którymi Kościół kieruje się prowadząc działalność misyjną. Są one następujące:

1. Wszyscy należący do Kościoła są zabowiązani prowadzić ewangelizację i głosić prawdę Chrystusową, zwłaszcza tym, którzy jej nie znają.

2. W głoszeniu tej prawdy nie wolno stosować przymusu i przemocy, ale ukazywać wielkość i moc prawdy ewangelicznej, popierając to świadectwem swego życia.

3. W ewangelizowaniu narodów nie znających Ewangelii należy uszanować prawdziwe wartości ich kultury, tradycji, historii, zwyczajów i obyczajów oraz wciągnąc je w ewangelizację.

4. Zakładając w krajach misyjnych młode Kościoły należy tamtejszych wiernych, zarówno kapłanów, zakonników jak i świeckich wprowadzić

49 Por. tamże, n. 3.

50 Archiwum Kurii Metropolitalnej w Krakowie, maszynopis. 
na drogę samowystarczalności a nawet zaangażowania w misjach $u$ innych narodów.

Zasady powyższe przypomniane przez Sobór są bardzo bliskie tej działalności misyjnej, jaką sześć wieków temu prowadzili misjonarze polscy, ewangelizując Litwę. Przypominając tę wiekopomną działalność Kościoła Polskiego, warto zaznaczyć jak bardzo już wtedy dzieło misyjne naszych przodków było bliskie temu, czego po wiekach nauczał w tej dziedzinie Sobór Watykański II.

\section{RECHTLICHE FESTSTELLUNG DER MISSIONSTÄTIGKEIT DES VOLKES GOTTES}

\section{Z u s a m m e n f a s s u $\mathrm{g}$}

Dem Gebote Christi gemäss soll die Kirche allen Völkern der Erde das Evangelium verkünden. Dass II Vatikanische Konzil hat im Hinblick auf die gegenwäritge Lage der Kirche in der Welt dem ganzen Volke Gottes die Pflicht der Evangelisation in Erinnerung gebracht. Alle Glieder der kirchlichen Gemeinschaft sind mitverantwortlich für die Missionsarbeit der Kirche. Die Vielgestaltigkeit der kirchichen Tätigkeitsgebiete bewirkt auch die Vielfalt der Missionsaufgaben.

Das Bischofskollegium unter der Führung des Bischofs von Rom leitet die Missionstätigkeit der Kirche, an der die Priester, die Ordensbrüder und die Laien teilnehmen. Die Konzilslehre bestimmt die Missionsaufgaben den Gläubigen - Priestern und Laien, die in traditionell christlichen Ländern wohnen, als auch djen Gläubigen in den Missionsgebieten. Alle sollen bei der Evangelisation der Völker mitarbeiten.

Die Leitlinien des Konzils für die Missionsarbeit sind in der Form von Gesetzesvorschriften der nachkonziliaren Gesetzgebung gegeben, anschliessend an das neue Gesetzbuch des kanonischen Rechtes. Diese Vorschriften weisen den einzelnen Gemeinschaften und Gruppen des Volkes Gottes ihre Aufgaben an. Sie bestimmen den Aufbau der Missionsarbeit der Kirche. Der Papstst führt das Missionswerk durch die Kongregation der Völkerevangelisation, die mit den päpstlichen Missionswerken mitarbeitet. In den einzelnen Ländern führen die Missionsarbeit die Bischofskonferenzen durch die zuständigen Kommissionen für Missionsangelegenheiten. In Polen wird diese Arbeit von der Episkopatskommission für Missionsangelegenheiten geleistet. 